\title{
Working-class Commuters and Innovative Use of Associational Power: The Case of Mamelodi Train Sector in South Africa
}

\author{
Mpho Mmadi, University of Pretoria, South Africa
}

\begin{abstract}
The article analyses the power resources of working-class train commuters in Tshwane, South Africa. I examine the organisational strategy of Mamelodi Train Sector (MTS), considering the crisis of representation characteristic of the South African labour movement currently. With changing composition of membership in the Congress of South African Trade Unions, the article begins with the question, what strategies and avenues are there for both unions and unorganised members of the working class? Through the case study of MTS, I suggest a need to rethink power resources and strategies in order to appreciate various non-union ways in which workers continue to organise under conditions that are at times hostile to unions. Drawing on the Power Resources Approach, I argue that MTS can utilise its strategic site of operations and associational power to link unorganised workers with relevant unions. Through its on-train organising, MTS strategically uses its associational power to achieve two things: 1) to empower non-unionised workers, and 2) to influence local-level politics during the morning and afternoon commutes.
\end{abstract}

\section{KEYWORDS}

Mamelodi Train Sector; train; comrades' coach; associational power; political agency

\section{Introduction}

The article analyses the associational and societal power resources of working-class train commuters in Tshwane, a municipality in Gauteng province of South Africa, organised under the Mamelodi Train Sector (MTS). A considerable body of work details the successes and challenges faced by labour movements globally. The bulk of this literature focuses on formal unions as vehicles through which to achieve workplace citizenship (Atzeni, 2020). Unlike traditional trade unions, MTS organises a broad cross-section of the working class on the trains during the morning and evening train commute. Train travel, although comparatively cheaper than mini-bus taxis and buses, remains expensive for those with meagre earnings. While travel costs are a burden for working-class commuters everywhere in the world, the significant travel distance resulting from the erstwhile apartheid government's spatial engineering highlight the material impact of commuting in South Africa. As a train-based, non-union organisation, MTS is strategically placed to mobilise against train fares, mobilise for local political office and provide guidance on workplace issues through labour law education and information on unions affiliated to the Congress of South African Trade Unions (COSATU) in each sector of the South African economy. This is in light of a crisis of representation with casualisation, externalisation and informalisation replacing standard employment relationship (SER) (Webster and Buhlungu, 2004: 234; Theron, 2005: 305; 
Bezuidenhout, Bischoff and Nthejane, 2017). Contrary to this picture of decline, MTS shows how non-union forms of organising, focused on issues of interest to a broad cross-section of the working class, has the potential to strengthen associational and societal power of the working class in an environment hostile to unions. Associational power refers to power that emerges from formations of workers' political parties or trade unions, while societal power speaks to labour's ability to draw in cooperation from other social actors. The Power Resources Approach (PRA) provides a way to analyse what power resources might remain open to workers in this context. For MTS, there are particular opportunities to mobilise associational and societal power. This is encouraged by counter-narratives that eschew the discourse around the crisis in the labour movement and its related general decline. The PRA is central to this endeavour and aims to project labour as an innovative force (Schmalz, Ludwig and Webster, 2018: 113).

In a 2018 Special Issue, the Global Labour Journal profiles cases of innovative use of power and new forms of organisational repertoires (Schmalz et al., 2018). To the extent that MTS is not a trade union in the traditional sense, I draw parallels with Kumar and Singh (2018) and Spooner and Mwanika (2018). Kumar and Singh show how the National Association of Street Vendors of India (NASVI) managed to organise street vendors by drawing on their vast numbers in order to build formidable associational power. This was done through associations of informal workers rather than the traditional trade union. Over time, this organisational capacity translated into societal power through strategic use of media campaigns and positive packaging of issues related to street vendors (Kumar and Singh, 2018: 137-138). Spooner and Mwanika (2018) similarly demonstrate how the Amalgamated Transport and General Workers' Union (ATGWU) achieved similar outcomes in Uganda. They note how the adoption of the Structural Adjustment Programmes (SAPs) in 1980 led to mass retrenchments and collapse of large bus companies, and in the process wiped out the membership base of ATGWU (Spooner and Mwanika, 2018: 151). With the collapse of the more traditional forms of transportation, informal minibuses and motorcycle taxis (bodabodas) took up the space as the backbone of public transportation in Uganda. Unlike street vendors, transport operators have considerable structural power because of their ability to bring whole towns and cities to a standstill. Structural power refers to the position of wage earners in the economic system and the extent to which they can use this position to cause disruptions that interrupt or restrict the ability of capital to realise profits (Schmalz et al., 2018: 116). Spooner and Mwanika estimate that the organised minibus taxi associations, such as the Kampala Operational Taxi Stages Association (KOTSA) and those organising boda-boda operators, have a combined membership of 70000 . Armed with both associational and structural power, ATGWU, as a recognised trade union, offered these associations institutional power. Institutional power is a form of secondary power that results from organised labour struggles and negotiations. It normally takes the form of legally fixed rights enshrined in legislation (Schmalz et al., 2018: 119-120; Spooner and Mwanika, 2018: 153). Using its resources, ATGWU supported the new affiliates through collective bargaining and by using its institutional power to negotiate with the local authorities on behalf of its members in the informal sector. In addition, ATGWU provided training on leadership. The two case studies are similar to MTS in that they managed to organise unorganised workers and selfemployed street vendors into organisations or associations that gave them voice. However, unlike MTS, NASVI and ATWGU have also successfully engaged with local authorities to win gains for members. Other than negotiating with the train operator and influencing local-level election, MTS falls short of these achievements. More significantly, however, NASVI and ATGWU serve as blueprints for what is possible and, in this regard, are important for demonstrating what potential impact MTS holds.

In the pages that follow, I demonstrate how MTS has managed to fill the "representational 
gaps" left by the erstwhile grassroots structures reminiscent of the social movement unionism (SMU) of the past. Through its on-train organising, MTS strategically uses its associational power to achieve two things: 1) to empower non-unionised workers to understand the value of unions, organising and the important use of labour laws as protection against abuse and exploitation; and 2) to influence local-level politics. Much like how street committees or civics were used in the past, MTS continues to be used as a campaigning tool by local councillors aligned to the African National Congress (ANC). According to Cherry, Jones and Seekings (2000: 890), civic organisations of the 1980 s had a great deal of power over local development issues. Thus, the ANC, which was banned at the time, relied heavily on local-level structures in communities to mobilise for local and national elections. MTS, with its roots in the 1970s, comes from the same tradition.

This article is based on an ethnographic study and employed participant observation for data collection. This meant travelling on the train both in the morning and afternoon, Monday to Friday. Being on the train allowed me an opportunity to observe first-hand the activities of MTS on the train. I carried a voice recorder in order to capture discussions, singing and the mood in the coach, as well as a notebook to capture significant events and dates. In addition to travelling on the train, I attended and participated in the organisation's monthly meetings, held on the last Sunday of every month at the local primary school in Mamelodi township. Because MTS organised six trains, I alternated days and weeks to observe different coaches. The first morning train departed Pienaarspoort station in Mamelodi at 04:30 and the last evening train left Pretoria station at 19:00. Being a participant, my own first-hand observations and experiences are presented as empirical data where appropriate. Because certain phenomena could not be observed, for clarification purposes I interviewed a few leaders; their real names have been replaced with pseudonyms. Due to rail upgrades, the train schedule was often severely affected, to the extent that it became impossible to re-establish contact with some of the members; this affected the study's ability to follow up and obtain clarity on certain critical points.

In what follows, I outline the basic tenets of the PRA and its application in South Africa, linking to a brief history of the South African labour movement and its strategic use of power against both the apartheid state and capital. Considering the well-documented decline of organised labour, I demonstrate MTS as a strategic choice and a possible model through which South African labour movement can be renewed.

\section{The Emergence of Institutionalised Industrial Relations in South Africa}

The PRA departs from the basic premise that labour can successfully defend its interests through collective forms of mobilising available power resources in the structurally asymmetric and antagonistic relationship between capital and labour. Power is understood, in the first instance, as the power to do something; this is referred to as power to. On the other hand, there is power to determine the rules of engagement, which is power over (Schmalz et al., 2018: 113). This recognises the fact that the PRA is a relational concept because employers are also able to mobilise power resources in order to undermine labour efforts or reach certain agreements. Furthermore, and most importantly, the PRA is not only concerned to analyse structural power relations, but also interested in understanding the ability of wage earners to assert their interests within particular contexts. In the South African context, the 1980s can arguably be presented as the golden era of labour's power to. Starting in Durban in 1973, South African workers relied heavily upon structural power, derived from South Africa's industrial model unionism based on the Fordist labour process characteristic of the manufacturing sector. The production process relied on a large pool of workers concentrated in one space; in this scenario, production could be effectively disrupted (Buhlungu, 2001: 187). In 
this way, workers won concessions from both the racist apartheid state and employers by making workplaces and communities ungovernable. Lacking both political and industrial citizenship, the South African labour movement adopted a class-based strategy that combined radical vision with reform - a radical reform (Adler and Webster, 2000). The union movement emphasised legal means of struggle against both employers and the state with a view to eventually ending apartheid. With this vision, the unions registered and participated under the Labour Relations Act (LRA) of 1981, following the Wiehan Commission of 1979. Radical reform allowed the labour movement to use its strong shop-floor base to incrementally push for concessions first from employers and in the process to democratise the workplace and win recognition and inclusion for all workers. This allowed workers the space to fight for better working conditions and wages. With a strong power base established in the factories and anchored in democratic accountability of elected leadership to the rank and file, the union movement started to engage the oppressive state and demand citizenship rights. Radical reform also allowed the labour movement to be tactically flexible. Tactical flexibility refers to the ability to differentiate principle from tactics, thus knowing when to negotiate and when to compromise (Adler and Webster, 1995: 80; Adler and Webster, 2000: 2).

COSATU aligned with the nationalist African National Congress and the South African Communist Party (SACP) and began to demand changes that extended beyond industrial relations, and could easily mobilise the whole society in defence of its demands. Business boycotts and stayaways were common during this time. Being able to harness sources of power beyond the factory gate and to defend community interests under one umbrella body, the South African labour movement assumed a new character - social movement unionism. This form of trade unionism is characterised by shop-floor participatory democracy, with a focus not only on union bread-andbutter issues but also encompassing struggles around socio-economic demands by building collaborative alliances with other social actors (Lambert and Webster, 1988; Webster, 1988; Scipes, 1992; Seidman, 1994; Hirschsohn, 2007). This power was translated into real gains both on the shop floor and in society at large. Starting with the collapse of apartheid in the early 1990s and the adoption of a progressive legislative framework such the Labour Relations Act of 1995, the South African labour movement truly had a positive impact transforming the country. Among others, the LRA aimed to bring all employees into one industrial relations system. The Act promoted collective bargaining and secured organisational rights for workers. It paved the way for a dispute resolution mechanism by establishing a Commission for Conciliation, Mediation and Arbitration (CCMA), and provided rules around dismissals to be managed by the Labour Court. The LRA has since been supplemented by the passage of the Basic Conditions of Employment Act (BCEA) of 1997 and the Skills Development Act of 1998. These were aimed at further extending protection to the vulnerable section of the labour force as well as providing much-needed skills. This legislation intended to provide the basis for institutionalising industrial conflict and to give voice to the marginalised in an institutional forum like the National Economic Development and Labour Council (NEDLAC), a tripartite body consisting of representatives of labour, employers and the

government. NEDLAC is meant to facilitate dialogue and serve as a consensus-building mechanism around issues such as economic and social policies (Adler and Webster, 1995, 2000; Webster and Adler, 1999; Buhlungu, 2001, 2010; Satgar and Southall, 2015; Craven, 2016; Webster, 2017; Mmadi, 2018).

\section{Limitations of the Formal Industrial Relations System}

The above gains have come under pressure with the changing nature of work. Recently, a few concerning observations have been made with regard to the South African labour movement. First, 
and following global trends, the South African labour movement has been on the decline postapartheid, devastated by the changing nature of work as exemplified by what Theron (2005: 305) refers to as a trinity of interlocking processes. This refers to the interwoven workplace restructuring process represented by casualisation, externalisation and informalisation. It speaks to a process of workplace differentiation identified by Von Holdt and Webster (2005) in which workers can be grouped into three major zones. First, there is a group of core workers, employed under the standard employment relationship contract. It is noteworthy that the majority of COSATU's members are concentrated here (Satgar and Southall, 2015: 28; Bezuidenhout and Tsoaedi, 2017). The second zone represents non-core workers made-up of casuals and externalised workers. The third zone is the periphery, where individuals make a living through informal sector activities.

Casualisation, externalisation and informalisation have fractured worker solidarities. As a result, the trade union movement is currently faced with a crisis of representation (Kenny, 2004: 486-888; Webster and Buhlungu, 2004: 234). This crisis of representation points to the fact that those at the margins of the labour market have been left to fend for themselves. Bezuidenhout et al. (2017: 48-49) suggest that COSATU is currently dominated by public-sector unions with an average monthly income of R12 361.26 (USD 806.62). This is explained by reference to the changing composition of union membership in which workers acquire sufficient educational qualifications to advance salary earnings and benefits. These are typically nurses, teachers and managers in the public service. Even with the recently increased national minimum wage of R21.69 (USD 1.42) per hour, it is clear to see why COSATU members are characterised as labour aristocrats (Bischoff and Tame, 2017: 61; Bhengu, 2021).

The above can be linked with the second concern. Webster (2017) argues that there has been a disconnect between associational power and institutional power. He observes that, postapartheid, organisations that championed the new labour regime have become increasingly disconnected from the institutions such as NEDLAC and others (Webster, 2017: 149; Schmalz, et al., 2018: 128). The declining capacity and ability of labour to organise effectively has ensured that the interests of workers have received little attention at the institutional level.

The failure to use power effectively can be accounted for and arguably collapsed into our third concern - the decline, if not the complete disappearance, of social movement unionism. Postapartheid, several commentators have observed how COSATU has become a shadow of its former self, considering its failure to uphold the SMU strategy of cross-sectional bargaining that held sway in the 1980s. That the federation has increasingly focused its organising muscle in the public sector has raised questions about whether COSATU is still a working-class movement (Bezuidenhout et al., 2017). Those who argue that social movement unionism of the past has been demobilised point out that this is due to the qualitative change in conditions (Lier and Stokke, 2006: 806; Seidman, 2011: 94). At the height of labour militancy, the South African social movement unions were able to harness the full might of their power in pursuance of SMU goals.

I demonstrate that rethinking power resources and strategies has revealed how workers continue to organise in ways that not only ensure that the social movement unionism of the past remains a possibility, but most importantly that grassroots organisations can be revived. The focus, however, is not whether Mamelodi Train Sector constitutes a form of SMU, but how it utilises its associational and societal powers in service of commuter working-class members.

\section{MTS and Power Resources: Limits and Possibilities}

Schmalz et al. (2018: 124) state that the concept of power resources is not a universal and static formula but should be deployed strategically as the context demands. The cases presented in the 
2018 Special Issue on the PRA make it clear that labour revival cannot be a one-size-fits-all approach. The case of Mamelodi Train Sector, as will be shown, bears both similarities and differences to a typical South African worker organisation. Arguably, the organisational repertoires of this train-based movement draw from the long history of South African social movement unionism. MTS forces into the discourse a somewhat neglected aspect of the South African working class - the important role of the train as both a point of worker convergence and a strategic site of mobilising. There can be little doubt that South African working-class associational power is a conventional, factory-based, shop-floor structure with an affiliation to the national office in the form of COSATU. MTS, however, is a train-based, working-class commuter organisation that operates as an "organising structure" for the ANC-SACP_COSATU alliance.

The organisation itself dates all the way to the 1970s and was formed as a defensive unit for workers in Tshwane against the violence perpetuated by Inkatha Freedom Party (IFP) supporters, many of whom lived in hostels in Gauteng province (Mmadi, 2018: 148). ${ }^{2}$ The foundation for MTS was laid with the re-emergence of worker militancy. Train organising can be accounted for by the history of South Africa. It was at the height of political upheaval in the 1980s that trains became a site of struggle. To be sure, all of Tshwane's major black townships had organisations operating on the train. Mamelodi township was organised under Mamelodi Train Sector, Soshanguve township under Soshanguve Train Sector (STS), and Mabopane township under Mabopane Train Sector (another MTS). Collectively, these three train-based organisations formed an umbrella body called Tshwane Train Sector (TTS). Unfortunately, by the time of this research, only Mamelodi Train Sector was still in existence.

According to Pirie (1992), following the declaration of the State of Emergency in 1985 the trains assumed a very significant role as a point of convergence. As outdoor gatherings were banned, the train was utilised to subvert apartheid's security apparatus: "Train rallies ... [became the] new expression of the way in which public transport has long been used, both literally and figuratively, to mobile[s]e political resistance in South Africa" (Pirie, 1992: 179). In addition, Shubane (1988: 43) points out that during the State of Emergency mass meetings were banned; therefore, the train emerged in this context to fill the political gap. This had the added advantage of conscientising workers not already organised into trade unions. He notes how the proximity between the train station and Khotso House (later to become COSATU House), headquarters of the union federation, helped facilitate this process. At some level, this was a seamless process because "it was normal for striking workers to walk together to the [train] station after a meeting, board the same train, and continue discussing issues from the meeting" (Shubane, 1988: 45).

Therefore, while the apartheid Security Branch monitored workplaces and townships, the train facilitated contestation and solidarity. Most significantly, in the 1980s the train was able to facilitate a coordinated programme of action. This was reflected by two big strikes, one in 1986 and the other in 1987. These strikes were planned while workers were travelling to and from work. The 1986 strike involved the retailer, OK Bazaars; most of its customers were black, and the train was used to promote boycotting the store among commuters. Because commuters are at the same time

\footnotetext{
${ }^{1}$ Formed in 1990 shortly after the release of Nelson Mandela and other political prisoners from Robben Island, the Alliance is a loose political partnership between the three organisations.

2 Violence broke out in the East Rand townships of Katlegong, Thokoza and Vosloorus. These townships, which came to be known as KATORUS, became centres of violence perpetrated by hostel dwellers associated with the Zulu nationalist political party, the Inkatha Freedom Party. The IFP collaborated with the apartheid state in the so-called black-on-black violence that sought to derail the transition to democratic rule.
} 
residents, the message gained traction quickly in black communities. The train helped build and coordinate organising strategies between workplace-based workers' movements and community organisations (Shubane, 1988: 45). This strategy was adjusted in the democratic era.

\section{From Defensive Unit to an Alliance Structure: MTS post-1994}

Following the first democratic elections in 1994, MTS changed from its former character as a defensive unit organising for safety on the trains to one that worked on behalf of the ANC and its Alliance partners. The organisation was formalised as an organising structure for the Alliance in 2001. Its objectives as stated in the constitution are in line with how it uses its associational power. According to the constitution, MTS leadership structures are constituted as follows:

1. The President - who is the political head and the chief directing officer with powers to (a) preside over meetings; (b) conduct meetings as per the provisions of the constitution; and (c) shall be the ex-officio member of all structures.

2. Deputy President - exercises the powers and duties of the president in his/her absence and is the head of the disciplinary committee (DC).

3. General Secretary - is the chief administration officer of MTS.

4. Deputy General Secretary - deputises for the general secretary where necessary.

5. Treasurer General - chief custodian of the funds and property of MTS (MTS, 2001).

In addition to the top five positions, five additional members are elected to form the top ten, constituting the Executive Committee (MTS, 2001). The term of office for all elected positions is a maximum of two years. Train coaches are governed as follows:

1. Train Chairperson - elected from the floor and oversees the specific coach on the specific train.

2. Deputy Chairperson - elected from the floor and exercises the powers and responsibilities of the chairperson in his/her absence.

3. Train Treasurer - oversees members' joining fee as collected with respect to the specific coach. Expected to present complete financial statements to the executive committee in respect of the monies collected from members.

4. Train Secretary - administrator of the coach. Expected to assume leadership responsibility in the absence of both the Chairperson and Deputy Chairperson.

5. Deputy Secretary - exercises the powers of the General Secretory in his/her absence (MTS, 2001).

All members are expected to recruit members on behalf of MTS and the Tripartite Alliance. Train chairpersons and the leadership collective are expected to brief the Executive Committee meetings about developments in their respective coaches. As the constitution makes conspicuously clear, MTS is an organisation dedicated to the needs of workers, but also workers as citizens. Furthermore, membership is also open to students who travel on the train. Individual workers and students join MTS for an annual membership fee of R50 (USD 3.26) and R20 (USD 1.31) respectively, and thereafter a R20 yearly renewal for workers and R10 (USD 0.65) for students (Mmadi, 2018, 2019).

Mobilising for the Alliance means that MTS's associational power operates at two levels industrial and political. This is important for how we think about associational power and workers' political agency. I discuss each in turn and show how the two intermingle on the train floor. To be sure, the train has played a significant role in the making of the South African working class and 
remains an important part of workers' daily travel experiences (Mmadi, 2018, 2019; Van Onselen, 2019). Organising on the train, MTS suffers from a limitation: because it does not organise workers on the factory floor, it cannot access structural power and its related benefits. Discussions in the coach to and from work range from the Basic Conditions of Employment Act, the Unemployment Insurance Fund (UIF) and labour rights in general. For example:

Comrades, let me tell you. If you are unsure as to whether your employer deducts UIF levies, simply take your green barcoded ID [identity document] and walk into any Department of Labour and inform them you want to verify if your employer is UIF-compliant. Should it be that the employer is not compliant, the Department of Labour will furnish you with a so-called one-direction form. Fill it in and then hand it to the employer to ensure that monthly UIF levies are deducted from your salary (Recorded discussion, 29 October 2015).

On Tuesday 15 March 2015, when the floor was opened for complaints, an elderly man stood up. He was wearing a black and blue uniform with epaulettes; he indicated that he was a security guard. On his monthly payslip there are monthly deductions of R6 for something called PSiRA. He was not sure why this money was being deducted and needed to be educated around this. The Chairperson indicated that he himself was not well informed about it and asked fellow comrades to investigate this and assist the fellow worker. My own investigation indicated that PSiRA stands for Private Security Industry Regulatory Authority. All security guards are certified by this body, and this might explain the monthly deductions from its members.

Observations on 20 October 2015 help explain the important role played by MTS, particularly in relation to those workers without workplace representation. "Comrade Mama", ${ }^{3}$ the president of MTS, recognised one lady who stood up to take the floor after having put up her hand. She asked a question regarding her colleague who was given a suspension letter after a physical altercation with another colleague at work. Her grievance was that it would seem as if the employer's decision (to suspend her colleague) was biased. She emphasised the significance of her question, especially because most of the workers in the coach were not unionised. She and her colleague were members of the National Education, Health and Allied Workers Union (NEHAWU), but unfortunately her colleague was outsourced from NetCare to Campus; ${ }^{4}$ she was lucky that she retained her union membership. The problem, however, was that the union was reluctant to represent her colleague at the hearing because she was outsourced, despite her being a member in good standing of the union. This meant that she was technically un-unionised. In response the Train President indicated that NEHAWU had a duty to represent her colleague because she was still a member in good standing. NEHAWU shop stewards must assist, the president of MTS insisted. So, the President declared, this would be tomorrow's topic of discussion: "What to do when an employee is faced with a disciplinary hearing (DC)". The President pointed to one of the comrades (whom he knew to be a shop steward) and asked him to come prepared the next day to educate fellow workers on this particular issue. Delivering a word of caution, the MTS President warned against self-representation in disciplinary hearings. He pointed out the importance of being represented in order to avoid getting emotional and making mistakes during

\footnotetext{
3 "Mama" is a cultural term of respect, meant to acknowledge women and their role as mothers or as elders.

${ }^{4}$ NetCare Limited is one of the leading private healthcare providers in South Africa, with subsidiaries such as hospitals and pharmacies. Campus Cleaning Services provide cleaning, with operations in hospitals and institutions of learning. NetCare outsourced cleaning services to Campus, meaning that the majority of its former cleaning staff lost their association with NetCare but continued to work on its premises through a client contract relationship. This type of third-party employment is generally not unionised in South Africa.
} 
DC proceedings. Also, he said, if you are alone in a DC it means you have no witnesses. Thus, in the event of a dispute, it will be your word against that of the employer, and such a scenario weakens the employee's case. Among many of COSATU's successes as a social movement union was its ability to build grassroots organisations that became the lifeblood of its organisational strength. Indeed, Schmalz et al. (2018: 127) lament the death of grassroots organisations as having contributed to the disconnect between institutional power and the organisations that created them. MTS might lack shop-floor associational power, but perhaps its strength and avenue of possibilities is its ability to keep workers mobilised. By educating workers about labour legislation, MTS arguably creates a direct link between workers and institutional forms of protection. This reiterates the point around rethinking how we mobilise power resources and related strategies. As the education on disciplinary hearings has demonstrated, to access some of the institutionalised power one need not always be reliant upon direct industrial action. Workers can be capacitated through education.

Because MTS is an organising structure of the Alliance, it subscribes to democratic centralism. This means that, following broad discussion, policy and strategies are decided centrally and are binding on all structures. In line with this, COSATU's "one industry, one union; one federation, one country" approach means that MTS cannot be involved in union work (SAHA, 1987). Consequently, through its links with COSATU-aligned unions, MTS simply identifies nonunionised workplaces and then relays such information to the unions concerned. Where the union is unable to immediately assist, MTS would intervene by encouraging workers to form a committee and have the union send an organiser. The train, MTS's site of organising, affords access to workers from various industries and workplaces.

In addition to the above and a clear example of the use of societal power, MTS regularly engages the Passenger Rail Agency of South Africa (PRASA) on train fare increases. Ahead of yearly train fare increases, MTS would normally call a meeting of commuters and, based on decisions reached, present a list of demands to PRASA. One of the key concessions to be won by MTS on behalf of workers was to have PRASA issue letters to workers at the various train stations when train schedules were disrupted, be it due to theft of overhead electrical cables or trains having broken down. These letters would have the PRASA letterhead and official stamp and could be provided to employers as evidence of why employees were late for work. Through the efforts of MTS, and with PRASA hoping to depoliticise its engagements with commuters, a Tshwane Commuters Forum was formed. The forum was meant to replace MTS in all engagements with the rail operator. Conversations with MTS leadership reveal that the Commuters Forum was the death of Tshwane Train Sector because the leadership, together with that of Mabopane and Soshanguve sectors, joined the PRASA-sponsored Commuters Forum for financial gain and employment opportunities with the rail operator. It is important to appreciate that workers' issues cannot be limited to workplace bread-and-butter matters. To this extent, MTS is also involved in politics; it campaigns for the ruling ANC and actively supports and encourages its members to run for ward counsellorship positions during local government elections.

The second aspect of MTS is its associational power at the political level. There is evidence that the organisation has had some notable success in local-level political contestations. For MTS the political space is very important as it is one among other avenues to ensure that workers' interests are protected. To this end, MTS mobilises its associational power within the Alliance to secure local-level political influence and power. Workers are also citizens, and thus require housing, running water and other basic services. By developing its associational power in this way, MTS ensures that the local political office is occupied by a candidate friendly to the working class.

Observations from late April into May 2016 indicate that the comrades' coach increasingly 
became a political platform. This finding was a distinct characteristic of the 05:45am train number 91:16. Chairperson of the coach, Comrade Maponya, was campaigning for the position of ward councillor in Mamemlodi East, Ward 10. Inevitably, Comrade Maponya dedicated a substantial amount of time talking elections as well as encouraging fellow commuters to register for the upcoming local elections. The following three messages were announced on 19 May 2016 immediately after the singing of national anthem:

(1) Comrades please note that the $23^{\text {rd }}$ of May 2016 is the last day for local elections voter registration.

(2) ANC will be hosting a regional manifesto launch at Atteridgeville on the 29th of May 2016. Comrades are requested to attend the manifesto launch in their numbers. Sixteen buses will depart from Mamelodi on the day.

(3) On the $4^{\text {th }}$ of June, ANC will launch the provincial manifesto at FNB Stadium (Recorded discussion in the coach, 19 May 2016).

Comrade Segoa explains why MTS chose and supported Comrade Maponya to contest for a councillor position in the local elections:

Because we are members of society, we are not only going to discuss issues affecting workers. Even social issues at home, we need to discuss those issues and political issues. One of the Congress resolutions we took was that MTS shall serve as a campaigning structure of the Alliance ... As workers we can't only be active at work through unions, because at times workplace problems are linked and are as a result of political problems. People need to understand that aspect. For example, if I speak about the Labour Relations Act, that Act came about because of the political organisation currently in Cabinet. So, to achieve some of our objectives as workers, we needed to have influence at the political level ... So, we saw it fit as a campaigning structure to deepen our participation in these [political] platforms ... That is why [the] majority of MTS members are leaders elsewhere in society. We agreed that we needed to see our members in government; we are having councillors. The first thing we agreed was that let's target Ward 10. And we said Comrade [Maponya] must be a councillor because there are issues there. And we want to see Train Sector represented there because members of the Train Sector shall, from time to time, represent the working class. We considered Comrade [Maponya] and we managed to be successful ... What we are doing is to encourage comrades at Ward 10 that this is a suitable candidate and we're providing them reasons for our candidate (Interview with Comrade Segoa, 14 September 2017).

For those seeking political office, the comrades' coach provides access to a captive audience with deep-rooted community ties. Generally, there exists a connection between workplace and community leadership roles. This means that an attempt to separate the world of work from the community as a place from which workers come is a naïve and futile exercise. The case of MTS, as detailed in these pages, demonstrates that solidarity is varied and thus it is important to appreciate different labour tactics. South African social movement unionism and similar movements that emerged elsewhere in the Global South have made a powerful case regarding broadening workingclass power beyond the workplace. Further, MTS provides scope for a broader understanding of associational power and sites of organising. The train is arguably intricately linked with the exploitation and oppression experienced by the majority of the South African working class (Mmadi, 2018; Van Onselen, 2019). To this end, it comes as no surprise that it is a site of worker/commuter organising. 


\section{Railway Upgrades and the Silent Coaches}

In March 2016, PRASA issued a communique informing commuters of a pending process of rail line upgrades that was due to commence in April and be completed by September of the same year. The upgrades resulted in the closure of certain rail lines. Due to these upgrades, trains used a much longer corridor to access the central business district (CBD), from which workers connect to various parts of Tshwane and Gauteng. The upgrades were in line with the expected introduction of new train models. The consequence of this process was a) longer commuter waiting periods, b) delayed train departure and arrival times, c) trips characterised by frequent stop and go, and lastly, d) overcrowding. What followed was a deafening silence in coaches that are usually characterised by speeches, education, song and dance. A sense of lack of direction descended upon the comrades' coach. Every morning, a discernible feeling of longing had become the proverbial elephant in the coach. The upgrades and, most importantly, the subsequent introduction of the new train models exposed the fragility of the comrades' coach. Furthermore, the new model poses a real threat to the very existence of MTS as an organisation. This is because the new trains have a lower maximum capacity per coach, making it difficult for large groups of people to converge in one carriage at the time. The train will not move when capacity in one coach is exceeded. The complaints about the impact of the disruptions started to become more prominent from around May 2016. In conversation, an MTS member on the platform while waiting for a train that was late stated:

Comrades, we need to march to PRASA offices and force them to improve their services to commuters. It is May now, and this means that midyear examinations are around the corner. The current disruptions are likely to negatively affect school learners, comrades. We must boycott Metrorail and force it to accede to our demands (Recorded discussion, 4 May 2016).

Inside the coach, after the chairperson opened the floor for announcements, the same member took to the floor and made the same point, but this time emphasising how the disruptions would lead to job losses:

Comrades, Amandla! Comrades, we need to do something about the train service disruptions. At this rate, most of us will lose our jobs, comrades, because we are always late to work. We need to march to PRASA offices, comrades, and demand better services, comrades. When I get to work, I will send an email to PRASA, comrades, and convey our unhappiness with the disruptions (Recorded discussion, 4 May 2016).

The disruptions informed the message that was delivered by the chairperson of train 91:10 on Tuesday, 17 May 2016:

There is a need to once again remind commuters about the [new] train schedule because some of you in here are newcomers and some of you just returned from leave. So, you might not know about the changes (Recorded discussion, 17 May 2016).

Present in the coach on the day was the General Secretary of MTS who was afforded an opportunity to address the coach:

I also want to talk about the issue of transport, comrades, because if we don't address the issue of transport, comrades, we are the ones who will be affected negatively because the issue of transport is linked to employment opportunities, comrades ... (Recorded discussions, 17 May 2016). 
The interview excerpts together with train-based observations demonstrate clearly the potential for organisations such as MTS. This is because the train is a permanent feature of working-class life in South Africa, and thus has merit for its use as a site of organising. At the same time, however, the train has also proved to be MTS's weakness is a site of organising.

Since PRASA commenced its railway upgrades in April 2016, MTS started to suffer sever setbacks as an organisation. This analysis is informed by the fact that the disruption meant that most of the recognised and elected leadership started using minibus taxis instead of trains to get to work. This weakness is not new in respect of South African worker organisations. Over and above the weakness due to leadership dependency, another worrying threat is structural. The new-model trains are smaller and designed to carry only a specified maximum commuter load. Because of this, PRASA has refused MTS permission to continue making use of the train as a worker space. MTS leadership has indicated that they will engage PRASA management to resolve the situation. For our purpose, the implications of these disruptions can be related broadly to the South African labour movement following the disintegration of the workplace due to outsourcing. The absence, both literal and theoretical, of a stable organising site exposes the vulnerability of nascent working-class organisations.

\section{Conclusion}

Studies coming out of both the Global North and Global South have demonstrated convincingly that capital has managed to dismantle some of labour's powers built over several years. Beverly Silver (2003), however, has cautioned against sounding the death knell of organised labour just yet. She has suggested that labour, while currently "unmade", is concomitantly being "remade" and "made" (Silver, 2003: 19). Without a doubt, the Global Labour Journal Special Issue of May 2018 has contributed to this line of thinking by demonstrating how workers, across workplaces, continents and spaces, are making strategic choices to reassert labour's interests (Schmalz et al., 2018). This speaks to the new forms of organising and sources of power (Webster and O'Brien, 2020).

These new forms of organising and sources of power have required labour scholars to look beyond the traditional trade union as the vehicle through which workers' demands can be met. In addition, workers have had to be imaginative and creative around sites of organising. MTS fits in with such modes of thought and labour revival strategies. Without a doubt, organisations like MTS give hope to many workers who have no other form of representation. The examples of NASVI and ATGWU demonstrate what can be achieved with a well-coordinated programme and willing leadership. Arguably, MTS can serve the union movement to link unions and workplaces. Most workers, as the examples of the security guard and Comrade Mama show, report workplace-based challenges to MTS. Affected unions could potentially benefit from this by dispatching organisers and shop stewards to assist and in the process show unorganised workers what unions can achieve. Of course, this will require considerable resources, but this can be gained back through increased membership.

Notwithstanding the fragility of this kind of organising, cases like this demonstrate what is possible and the varied ways in which labour can potentially respond to its weaknesses and challenges. Spooner and Mwanika (2018: 163) show that it is not so much that a single organisation has all the power resources at its disposal, but rather how it links up with other associations in order to counterbalance weakness. That MTS has managed to emerge as a key role player in local politics is undoubtedly important and potentially beneficial to workers. I am of the view that some of its limitations can be counterbalanced by linking up openly and deliberately with COSATU unions in various sectors, both organised and unorganised. Public transport remains a key cog in 
the South African economic life cycle, thus an important site to link workers with and across worker organisations.

\section{References}

Adler, G. and E. Webster (1995) Challenging Transition Theory: The Labor Movement, Radical Reform, and Transition to Democracy in South Africa. Politics and Society, 23(1): 75-106.

Adler, G. and E. Webster (2000) Trade Unions and Democratization, 1985-1997. London: Macmillan.

Atzeni, M. (2020) Workers' Organisation in Precarious Times: Abandoning Trade Union Fetishism, Rediscovering Class. Global Labour Journal, 11(3): 311-314.

Bezuidenhout, A., C. Bischoff and N. Nthejane (2017) Is Cosatu Still a Working-Class Movement? In Labour Beyond COS ATU: Mapping the Rupture in South Africa's Labour Landscape, edited by A Bezuidenhout and M. Tshoaedi. Johannesburg: Wits University Press.

Bezuidenhout, A. and M. Tsoaedi (2017) Democracy and the Rupture in South Africa's Labour Landscape. In Labour Beyond COSATU: Mapping the Rupture in South Africa's Labour Landscape, edited by A. Bezuidenhout and M. Tshoaedi. Johannesburg: Wits University Press.

Bhengu, C. (2021) Explained: The National Minimum Wage is Set to Increase in March - Here's What It Can Get You. Timelive, 2 October 2021. https://www.timeslive.co.za/news/south-africa/2021-0210-explained--the-national-minimum-wage-is-set-to-increase-in-march--heres-what-it-can-getyou/ \#: : :text=Employment $\% 20$ and $\% 20$ labour $\% 20$ minister $\% 20$ Thulas, $.76 \% 20$ to $\% 20$ R21.69 (accessed 17 February 2021).

Bischoff, C. and B. Tame (2017) Democracy and the Rupture in South Africa's Labour Landscape. In Labour Beyond COS ATU: Mapping the Rupture in South Africa's Labour Landscape, edited by A. Bezuidenhout and M. Tshoaedi. Johannesburg: Wits University Press.

Buhlungu, S. (2001) Full-time Officials and the Dilemma of Leadership: A Study of the Dynamics of Democracy and Power in the Post-1973 Trade Unions. Unpublished PhD thesis, University of the Witwatersrand, Johannesburg.

Buhlungu, S. (2010) A Paradox of Victory: COSATU and the Democratic Transformation in South Africa. Pietermaritzburg: University of KwaZulu-Natal Press.

Cherry, J., K. Jones and J. Seekings (2000) Democratization and Politics in South African Townships. Journal of Urban and Regional Research, 24.2(12): 889-905.

Craven, P. (2016) The Battle for COSATU: An Insider's View. Johannesburg: Bookstorm.

Hirschsohn, P. (2007) Union Democracy and Shopfloor Mobilization: Social Movement Unionism in South African Auto and Clothing Plants. Economic and Industrial Democracy, 28(1): 6-48.

Kenny, B. (2004) Selling Selves: East Rand Retail Sector Workers Fragmented and Reconfigured. Journal of Southern African Studies, 30(3): 477-498.

Kumar, S. and A. Singh (2018) Securing, Leveraging and Sustaining Power for Street Vendors in India. Global Labour Journal, 9(2): 135-149.

Lambert, R. and E. Webster (1988) The Re-emergence of Political Unionism in Contemporary South Africa? In Popular Struggles in South Africa, edited by C. William and C. Robin. Trenton, NJ: Review of African Political Economy/Africa World Press.

Lier, D. and K. Stokke (2006) Maximum Working Class Unity? Challenges to Local Social Movement Unionism in Cape Town. Antipode, 38(4): 802-824.

Mamelodi Train Sector (MTS) (2001) Constitution. Unpublished document.

Mmadi, M. (2018) Mzabalazo on the Move: Organising Workers on a Commuter Train in Tshwane - An Ethnographic Study of the Mamelodi Train Sector. Unpublished PhD thesis, University of Pretoria.

Mmadi, M. (2019) Mzabalazo on the Move: Organising on a South African Commuter Train. Journal of Southern African Studies, 45(5): 895-909.

Pirie, G.H. (1992). Travelling under Apartheid. In The Apartheid City and Beyond: Urbanisation and Social Change in South Africa, edited by D.M. Smith. London: Routledge.

Satgar, V. and R. Southall (2015) COSATU in Crisis: Analysis and Prospects. In COSATU in Crisis: The Fragmentation of an African Trade Union Federation, edited by V. Satgar and R. Southall. Sandton: KMM Review Publishing.

Schmalz, S., C. Ludwig and E. Webster (2018) The Power Resources Approach: Development and Challenges. Global Labour Journal, 9(2): 113-134. 
Scipes, K. (1992) Understanding the Labor Movement in the "Third World": The Emergence of Social Movement Unionism. Critical Sociology, 19(2): 81-101.

Seidman, G. (1994) Manufacturing Militance: Workers' Movements in Brazil and South Africa, 1970-1985. Oakland, CA: University of California Press.

Seidman, G. (2011) Social Movement Unionism: From Description to Exhortation. South African Review of Sociology, 42(3): 94-102.

Shubane, K. (1988) Emzabalazweni! There's Politics on the Train. South African Labour Bulletin, 13(7): 4347.

Silver, B. (2003) Forces of Labour: Workers' Movements and Globalization since 1870. Cambridge: Cambridge University Press.

South African History Archives (SAHA) (1987) Hlanganani Basebenæi: Commemorating South Africa's Labour Movement. https://www.saha.org.za/workers/cosatu 1987 one industry one union one federation one country build the workers struggle $2 . h t m$ (accessed 20 December 2020).

Spooner, D. and J.M. Mwanika (2018) Transforming Transport Unions through Mass Organisation of Informal Workers: A Case Study of the ATGWU in Uganda. Global Labour Journal, 9(2): 150-166.

Theron, J. (2005) Employment is Not What It Used to Be: The Nature and Impact of Work Restructuring in South Africa. In Beyond the Apartheid Workplace: Studies in Transition, edited by E. Webster and K. von Holdt. Pietermaritzburg: UKZN Press.

Van Onselen, C. (2019) Night Trains: Moving Mozambican Miners to and from South Africa, circa 1902-1955. Johannesburg: Jonathan Ball.

Von Holdt, K. and E. Webster (2005) Work Restructuring and the Crisis of Social Reproduction: A Southern Perspective. In Beyond the Apartheid Workplace: Studies in Transition, edited by E. Webster and K. von Holdt. Pietermaritzburg: UKZN Press.

Webster, E (1988) The Rise of Social Movement Unionism: The Two Faces of Black Trade Union Movements in South Africa. In State, Resistance and Change in South Africa, edited by P.H. Frankel, N. Pines and M. Swelling. London: Croom Helm.

Webster, E. (2017) Marikana and Beyond: New Dynamics in Strikes in South Africa. Global Labour Journal, 8(2): 139-158.

Webster, E and G. Adler (1999) Towards a Class Compromise in South Africa's "Double Transition": Bargained Liberalisation and the Consolidation of Democracy. Politics and Society, 27(3): 347-385.

Webster, E. and S. Buhlungu (2004) Between Marginalisation and Revitalisation? The State of Trade Unionism in South Africa. Review of Political Economy, 31(100): 229-245.

Webster, E. and R. O'Brien (2020) Ten Years of the Global Labour Journal: Reflecting on the Rise of the New Global Labour Studies. Global Labour Journal, 11(1): 4-17.

\section{ACKNOWLEDGEMENT}

I would like to thank the two anonymous reviewers and the GLJ's editorial team for constructive criticism and guidance.

\section{BIOGRAPHICAL NOTE}

MPHO MMADI is a research associate in the Department of Sociology and a senior student advisor for the Faculty of Natural and Agricultural Science (NAS) at the University of Pretoria. [Email: Mpho.mmadi@up.ac.za] 